\title{
Az Európai Unió Szomáliai Kiképzö Missziója 2010-2019 között
}

\begin{abstract}
A tanulmány tárgya az Európai Unió Szomáliai Kiképző Missziójának (EUTM-S) 2010-2019 közötti afrikai szerepvállalása. Az elemzés elsősorban az EUTM-S megalakulására, kilenc éven átívelő kronológiájára, valamint a misszió mandátumába foglalt kiképzési célkitüzéseinek eredményességére koncentrál, továbbá a szerző saját tapasztalatait alapul véve kitér a magyar szerepvállalás részletes ismertetésére is. Következtetésünk szerint a kiképző misszió sikeressége önmagában nem lehet kulcsa a szomáliai bukott államiság megoldásának.
\end{abstract}

Kulcsszavak: Szomália, Afrika szarva, Európai Unió, biztonság, kiképző misszió

\section{Nagy Sándor: The European Union Training Mission in Somalia (EUTM-S) between 2010 and 2019}

The subject of the current study is the role of the European Union Training Mission in Somalia (EUTM-S) between 2010 and 2019 in the Horn of Africa. The analysis focuses primarily on the foundation of the EUTM-S, on its chronology over nine years and the efficiency of its training objectives. Nevertheless, the author touches on the functional details of the Hungarian Contingent based on his own experience. We will conclude that the success of the training mission itself can not be the key solution for Somalia's fragile state status.

Keywords: Somalia, Horn of Africa, European Union, security, training mission

\section{Bevezetés}

Bár Kelet-Afrikában az egykor bukott államként számon tartott Szomáliát ma már törékeny államként emlegetik, 2018-ban az ország a Fragile States Index előkelőnek cseppet sem mondható második helyén végzett 113,2 ponttal, lemaradva a 113,4 pontos Dél-Szudán mögött. ${ }^{2}$ Második helye hüen tükrözi gyengeségét, kétségtelenül kifejezi biztonságpolitikai kockázati tényezőit, de ez nem meglepő eredmény a 2009-2013 között, ${ }^{3}$ valamint 2016-ban

\footnotetext{
Nagy Sándor, okleveles biztonság- és védelempolitikai szakértő.

The Fund for Peace: Fragile States Index 2018: Issues of Fragility Touch the World's Richest and Most Developed Countries in 2018. [online], 2018. 04. 19. Forrás: fragilestatesindex.org [2019. 03. 13.].

3 The Fund for Peace: Failed States Index 2013: The Troubled Ten. [online], 2013. 06. 24. Forrás: fundforpeace.org [2019. 03. 13.]; The Fund for Peace: The Failed States Index 2012. [online], Forrás: reliefweb.int [2019. 03. 13.]; 2011 Failed States Index Released: Somalia ranked most troubled state; Finland takes best position. [online], 2011. 06. 20. Forrás: reliefweb.int [2019. 03. 13.]; The Foreign Policy: The Failed States Index 2010. [online], 2010. 06. 17. Forrás: foreignpolicy.com [2019. 03. 13.]; The Foreign Policy: The 2009 Failed States Index. [online], 2009. 06. 21. Forrás: foreignpolicy. com [2019. 03. 13.].
} 
is az első helyen végzett ország számára. ${ }^{4}$ Afrika szarván az 1990-es évek első felének eredménytelen nemzetközi békeműveletei, az ENSZ kéksisakos missziói (United Nations Operation in Somalia, UNOSOM I-II), ${ }^{5}$ a sikertelen olasz vezetésű Íbisz Hadmüvelet, ${ }^{6}$ valamint a katasztrofális kimenetelü mogadishui csata ${ }^{7}$ összességében eredményezték a nemzetközi aktorok kivonulását az országból 1995 márciusában, betöltetlen vákuumot hagyva maguk után. ${ }^{8}$

Az as-Sabáb terroristaszervezet 2002 és 2004 között alakult meg Szomáliában, és hamarosan az ország teljes területére megpróbálta kiterjeszteni fennhatóságát. ${ }^{9}$ Az as-Sabáb fö törekvésének a Mohamed Abdullahi Mohamed Farmajo elnök ${ }^{10}$ által vezetett - nyugati támogatást is élvezö - szövetségi kormány megdöntését tekinti. 2007-ben az Egyesült Nemzetek Szervezete (ENSZ) felhatalmazásával Szomáliába települt Afrikai Unió Szomáliai Missziójának (African Union Mission in Somalia, AMISOM) kezdetben sikerült megtisztítania a nagyobb városokat az as-Sabáb harcosaitól, azonban a későbbiekben megfigyelhetővé vált az as-Sabáb visszaszivárgása és újbóli megerősödése. ${ }^{11}$

A nyugati koalíciós erők Irakban és Afganisztánban végrehajtott kiképzési szakterületen elért eredményeik és tapasztalataik azt sugallták, hogy a lehetséges megoldás a szomáliai biztonsági erők újjászervezésében, kiképzésében, felszerelésében és fenntartásában rejlik az ország stabilizációja érdekében. Az ENSZ Biztonsági Tanácsának (ENSZ BT) határozata alapján 2010 áprilisában elindult az Európai Unió (European Union, EU) Szomáliai Kiképző Missziója (European Union Training Mission Somalia, EUTM-S), amelynek feladata kezdetben az Ugandai Népi Védelmi Erők (Uganda Peoples Defence Forces, UPDF) közremüködésével a Szomáliai Nemzeti Hadsereg (Somali National Army, SNA) kiképzése volt.

A tanulmány magyar vonatkozású aktualitása, hogy a Magyar Honvédség (MH) közel egy évtizedes szomáliai szerepvállalást követően, 2019. év elején befejezte és kivonta 4 fös kontingensét az afrikai országból, tehát a továbbiakban katonailag nem járul hozzá az EUTM-S-művelethez. A kivonás érdekessége, hogy Magyarország Kormánya

\footnotetext{
The Fund for Peace: Fragile States Index 2016 - Annual Report. [online], 2016. 06. 27. Forrás: fragilestatesindex.org [2019. 03. 13.].

5 Az ENSZ szomáliai békefenntartó és humanitárius küldetései. Lásd: United Nations Operation in Somalia (UNSOM). [online], Forrás: unsom.unmission.org [2019. 03. 13.]; UNOSOM I (1992-1993). Forrás: peacekeeping.un.org [2019. 03. 13.]; UNOSOM II (1993-1995). Forrás: peacekeeping.un.org [2019. 03. 13.].

6 Az Íbisz Hadművelet (Operation IBIS) egy olasz vezetésű hadművelet volt 1992-1994-ben Szomáliában, amely 12 olasz katona halálát és további 107 sebesültét tette mérlegre. Lásd: Ministero della Difesa: Somalia - UNOSOM „Ibis”. [online], Forrás: esercito.difesa.it [2019. 03. 13.].

7 A mogadishui csata folyamán 18 fö amerikai katona életét, 73 fö sebesültet, és egy fő helikoptervezető elhurcolását, bebörtönzését követelte 1993. október 3-4-én az UNITAF alárendeltségében végrehajtott Remény Helyreállítása Hadmüvelet (Operation Resolve Hope) keretében. Lásd: Battle of Mogadishu (1993) - Black Hawk Down. [online], Forrás: militaryfactory.com [2019. 03. 13.]; Biedermann Zsuzsánna: Genocídium és destabilizáció az afrikai nagy tavak régióban. A konfliktus gazdasági vetülete. Budapest-Pécs, IDResearch Kft. - Publikon, 2015.

8 Pusztai Dávid: A szomáliai kísérlet. Az ENSZ Biztonsági Tanácsának útkeresése a hidegháború utáni új világrendben. Budapest, Gondolat, 2015.

9 Stig Jarle Hansen: Al-Shabaab in Somalia. The History and Ideology of a Militant Islamist Group. London, C. Hurst \& Co. (Publishers) Ltd., 2016.

10 Fred Oluoch: Somalia's federal states gang up against Farmajo. [online], 2018. 09. 08. Forrás: theeastafrican.co.ke [2019. 04. 07.].

11 Nagy Sándor: Hogyan tovább Szomália? [online], 2017. 01. 11. Forrás: afrikablog.hu [2019. 03. 13.].
} 
2019. április elején bejelentette új Afrika Stratégiáját, amely többek között tartalmazza a magyar katonai szerepvállalás növelését a fekete kontinensen. ${ }^{12}$

Az elmúlt évtizedekben az as-Sabáb mindennapos terrorcselekményei tömegek halálát követelték föleg az AMISOM, az SNA és a civilek körében, ugyanakkor az EUTM-S személyi állományában eddig még nem okoztak halált és sérülést is csak egy ismert esetben. A terrorcselekmények kapcsán azonban fontos kiemelni a tényt, hogy a helyi szereplök felelősség- és szerepvállalása (local ownership), ${ }^{13}$ valamint az országban lévő aktorok pozitív hozzáállása nélkül az SNA kiképzése lehetetlen lenne, gyakorlatilag kudarcba fulladna, amely az EUTM-S működési jogosultságát is erősen befolyásolná. ${ }^{14}$

A tanulmány alapvetően az EU és Szomália elmúlt évek alatti kapcsolati rendszerének eredményéből indul ki. Bár idáig az EUTM-S a mandátumában foglalt kiképzési és tanácsadási feladatait nagyobb veszteségek nélkül hajtotta végre az as-Sabáb harcosainak árnyékában, valamint az SNA kevésbé tudott megfelelö hatékonysággal fellépni az iszlamista terrorszervezet támadásai ellen. Elemzők szerint ugyanis ez nemcsak a kiképzés hatékonyságán, hanem a háttérben húzódó kormányzati érdekeken is múlik. Azt is szem előtt kell tartanunk, hogy bár az as-Sabáb napjainkra meggyengült, és egzisztenciális fenyegetést kevésbé jelent, ugyanakkor továbbra is a régió legegységesebb és legadaptívabb szereplője. ${ }^{15}$

A tanulmány bemutatja az EUTM-S megalakulását, kilenc éven átívelö kronológiáját, illetve a misszió mandátumába foglalt kiképzés célkitűzéseinek eredményességét. Jelen elemzés nem ad keretet a gazdaságpolitikai és nagyhatalmi érdekek szomáliai analízisének, hanem kizárólag és specifikusan a fentebb említett kérdéseket boncolgatja.

\section{Az Európai Unió Szomáliai Kiképző Missziója (EUTM-S)}

Az EUTM-S bemutatása során fontos kiemelni a misszió két jelentős korszakát: egyrészt a 2010 és 2014 közötti időszakot, amikor a mandátumban előirányzott feladatait az ugandai helyszínü Bihanga Kiképzőtáborban (Bihanga Training Center, BTC) hajtotta végre, másrészről a 2014 és 2019 közötti időszakot, amikor a kiképzési és mentorálási feladatainak a szomáliai székhelyü Mogadishu adott otthont.

Az EUTM-S művelete 2010 tavaszán vette kezdetét, feladata az UPDF közreműködésével a szomáliai biztonsági erők kiképzése volt. A kiképzést kezdetben az ugandai helyszínű BTC-ben hajtották végre, amely fokozatosan - 2014 év első hónapjaiban - a szomáliai Mogadishuba került át, miután a BTC-t 2013. december 9-én bezárták. A következőkben bemutatom az EUTM-S ugandai települése során, azaz 2010 és 2014 közötti föbb eseményeket, a misszió mandátumait és az idevonatkozó magyar szerepvállalás fontosabb mérföldköveit.

12 Ime, a magyar kormány Afrika-stratégiája: segély, export, katonák és mintafarmok. [online], 2019. 04. 02. Forrás: hvg.hu [2019. 04. 18.].

13 A helyi szereplők felelősség- és szerepvállalása nagymértékben befolyásolja az adott országban települő nemzetközi szervezetek müködési feltételeit és hatékonyságát, továbbá kihat az országon belüli stabilizációs törekvések és békefolyamatok társadalmi megítélésére, támogatottságára is. Lásd: Local ownership. [online], Forrás: interpeace.org [2020. 03. 17.].

14 Marsai Viktor: Fönixmadár Afrika szarván - az as-Sabáb tevékenysége 2015-2017. Budapest, Nemzeti Közszolgálati Egyetem. 2020a.

15 Marsai Viktor: Az Öböl-államok szerepe Kelet-Afrikában. Marsai Viktor habilitációs eljárásának nyilvános vitája és előadása. PowerPoint előadás (28 dia). 2020b. 


\section{Az EUTM-S megalakulása, kronológiája}

2009. május 26-án az ENSZ BT 1872. számú határozatában hangsúlyozta, hogy elengedhetetlen a szomáliai biztonsági erők újjászervezése, kiképzése, felszerelése és fenntartása, és arra ösztönözte a tagállamokat, a regionális és nemzetközi szervezeteket, hogy ajánljanak fel technikai segítséget a szomáliai biztonsági erők kiképzéséhez és felszereléséhez. ${ }^{16}$ Az ENSZ BT 2009. július 20-án úgy határozott, hogy megbízza az EU-t, fokozza a szomáliai béke és fejlődés előmozdítására tett kötelezettségvállalását. Ennek érdekében az ENSZ BT megvizsgálta, hogy az EU milyen módon tudna hozzájárulni a - többek között a biztonság területén kifejtett - nemzetközi erőfeszítésekhez. ${ }^{17}$

2009. november 13-án az ENSZ BT kijelentette, hogy a szomáliai helyzettel kapcsolatos átfogó EU-s megközelítés keretében fontolóra kell venni a szomáliai biztonsági ágazat számára nyújtandó további EU-s segítségnyújtást, és ennek a támogatásnak egy szélesebb körü és összefüggő keretbe kell illeszkednie, amelynek részét képezi az AU-val, az ENSZszel és más releváns partnerekkel, különösen az Amerikai Egyesült Államokkal (USA) folytatott szoros EU-s együttmüködés és koordináció. Az ENSZ BT emellett az AU-val kapcsolatban kiemelte az AMISOM szerepének fontosságát. Az ENSZ BT továbbá jóváhagyta a Szomáliai Átmeneti Szövetségi Kormány (Somali Transitional Federal Government, TFG) biztonsági erőinek kiképzéséhez hozzájáruló esetleges európai biztonsági és védelemi miszszióról szóló válságkezelési koncepcióját, és kérte a tervezési munka folytatását. A Politikai és Biztonsági Bizottság ezt követően tervezési csoportot nevezett ki. ${ }^{18}$

2009. november 18-án, valamint 2010. január 23-án kelt levelében a TFG elismerését fejezte ki a szomáliai nemzeti biztonsági erők kiképzésének koordinálására irányuló, valamint a szomáliai béke és stabilitás érdekében tett EU-s eröfeszítésekkel kapcsolatban, továbbá biztosította az EU-t azon elkötelezettségéről, hogy felelősséget visel az újoncok felvételéért, kiképzéséért és megtartásáért, valamint hangsúlyozta a szélesebb biztonságágazati politika iránti elkötelezettségét. Az AU szomáliai különleges képviselőjének helyettese 2009. november 30-i levelében az AU Bizottsága nevében üdvözölt egy több mint 2000 fös szomáliai erő kiképzésére vonatkozó EU-s elképzelést. ${ }^{19}$ 2009. december 3-án az ENSZ BT kiválasztott egy lehetséges EU-s misszióra vonatkozó katonai stratégiai alternatívát. ${ }^{20}$

Az ugandai védelmi miniszter 2010. január 5-i levelében köszöntötte az EU-nak a szomáliai biztonsági ágazatot támogató tervezett misszióját, és felkérte az EU-t, hogy legalább egyéves időtartamban vegyen részt a szomáliai biztonsági erők ugandai kiképzésében. 2010. január 20-án az EU felajánlotta a TFG-nek, hogy hozzájárul a szomáliai biztonsági erők kiképzéséhez. Az EU Tanácsa 2010. január 25-én úgy határozott, hogy a szomáliai

16 United Nations Security Council: UNHCR Resolution 1872: The situation in Somalia. [online], 2009. 05. 26. Forrás: unscr.com [2019. 04. 07.].

17 United Nations Security Council: Report of the Secretary-General on the situation in Somalia. [online], 2009. 07. 20. Forrás: undocs.org [2019. 04. 07.].

18 United Nations Security Council: Report of the Secretary-General pursuant to Security Council resolution 1846 (2008). [online], 2009. 11. 13. Forrás: undocs.org [2019. 04. 07.].

19 Decisions Council Decision 2010/96/CFSP of 15 February 2010 on a European Union military mission to contribute to the training of Somali security forces. [online], 2010. 02. 15. Forrás: eur-lex.europa.eu [2019. 04. 07.].

20 United Nations Security Council: Statement by the President of the Security Council. [online], 2009. 12. 03. Forrás: undocs.org [2019.04.07.]. 
biztonsági erők kiképzéséhez hozzájáruló EU-s katonai missziót hoz létre Ugandában, ahol a szomáliai erök kiképzése már folyamatban volt. A misszió céljai között szerepelt, hogy megkönnyítse az EU-s fellépés összehangolását az AMISOM erőivel. 2010. február 15-én az EU Tanácsa 2010/96/KKBP határozata kimondta az EU-nak a szomáliai biztonsági erők kiképzéséhez hozzájáruló katonai missziójának megalakítását. ${ }^{21} \mathrm{~A}$ misszió 2010. április 7-én indult el a 2010/197/KKBP határozat alapján. ${ }^{22}$

2011. április 21-én az AU Bizottságának elnöke benyújtotta a szomáliai helyzetröl szóló jelentését a Béke- és Biztonsági Tanácsnak. Ebben hangsúlyozta a biztonság terén elért eredményeket, és a kiképzéshez nyújtott támogatás folytatását kérte. 2011. május 4-én az EU külügyi és biztonságpolitikai főképviselőjének írt levelében Szomália miniszterelnöke kifejezte a TFG nagyrabecsülését az EU segítségnyújtásával kapcsolatban. 2011. június 23-án a TFG a biztonsággal foglalkozó vegyes bizottság kampalai ülésén ismét előrevetítette, hogy mennyire fontosnak tartja az EU-s támogatást. ${ }^{23}$ 2011. július 28-án az EU Tanácsa elfogadta a 2011/483/KKBP határozatát az Európai Uniónak a szomáliai biztonsági erők kiképzéséhez hozzájáruló katonai missziójáról szóló 2010/96/KKBP határozat módosításáról és mandátumának meghosszabbításáról. ${ }^{24}$

2012. április 28-án az ENSZ fötitkára az ENSZ BT-nek készített jelentésében szorgalmazta azon javaslatát, hogy a nemzetközi közösség szereplöinek célszerü jelentős mértékben beruháznia Szomália fenntartható fejlődésébe, és ennek keretében egyebek mellett támogatnia a biztonsági ágazat megerősítését. ${ }^{25}$

A 2012. május 31. és június 1. során Isztambulban megtartott, Szomália helyzetével foglalkozó nemzetközi konferencia résztvevői elismerésüket fejezték ki az EU-nak az AMISOM-ot és a szomáliai biztonsági intézményeket támogató munkájáért. A konferencia résztvevői megállapították, hogy a nemzetközi közösségnek továbbra is támogatnia kell egy professzionálisan müködő, inkluzív, szabályokon alapuló és jól felszerelt biztonsági apparátus - ideértve a szomáliai hadsereget, rendőrséget, haditengerészetet, parti őrséget és a hírszerzést - újbóli létrehozását, és kiemelték annak szükségességét, hogy minden szomáliai erőt egységes parancsnokság alá helyezzenek. Szomália elnöke egy hatpilléres programot fogadott el, amely a stabilitást, a gazdasági fellendülést, a béketeremtést, a különböző közszolgáltatások nyújtását, a nemzetközi kapcsolatokat és az ország egységét hivatott ösztönözni, valamint amelynek értelmében a biztonsági rendszer reformja szilárd alapeleme az életképes szomáli államnak. Az elnök arra kérte az EU külügyi és biztonságpolitikai főképviselőjét, hogy az EU folytassa Szomália támogatásában vállalt szerepét. ${ }^{26}$

21 Council Decision 2010/96/CFSP.

22 Council Decision 2010/197/CFSP of 31 March 2010 on the launch of a European Union military mission to contribute to the training of Somali security forces (EUTM Somalia). [online], European Parliament, 2010. 03. 31. Forrás: europarl. europa.eu [2019. 04. 07.].

23 Council Decision 2010/96/CFSP.

24 Council Decision 2011/483/CFSP of 28 July 2011 amending and extending Decision 2010/96/CFSP on a European Union military mission to contribute to the training of Somali security forces (EUTM Somalia). [online], 2011. 07. 28. Forrás: eur-lex.europa.eu [2019. 04. 07.].

25 United Nations Security Council: Report of the Secretary-General on Somalia. [online], 2011. 14. 28. Forrás: undocs.org [2019. 04. 07.].

26 Republic of Turkey Ministry of Foreign Affairs: The Second Istanbul Conference on Somalia, Final Declaration, 1 June 2012, Istanbul. [online], 2012. 06. 01. Forrás: mfa.gov.tr [2019. 04. 09.]. 
2012. november 9-én az UPDF és amerikai katonai összekötő tisztek részvételével EUTM-S találkozót szerveztek a misszió főparancsnokságán, amelynek fö témája a bihangai képzés jövője volt. Az UPDF részéről Katumba Wamala altábornagy, a szárazföldi erők parancsnoka, a misszió képviselőin túl EU-részről Fernando Moreno az EU Kríziskezelési és Tervezési Főosztály osztályvezetője és Roberto Ridolfi az EU nagykövete, amerikai részről pedig a kampalai és nairobi nagykövetség küldöttei vettek részt a találkozón. Az amerikai fél elfogadta az akkori mandátum meghosszabbítására elöirányozott álláspontot, és deklarálta, hogy 2013-ban is támogatja a BTC-ben folyó képzést, de kizárólag 300 fő erejéig. Ez utóbbi álláspont egyértelműen a kiképzési koncepció teljes jövőbeni átdolgozását igényelte, hiszen a létszámot tekintve ez olyan szakkiképzést jelentett, amelyet az SNA igényeihez igazítottak. A szomáli erők egyébként már 2012. december 1-jén megkezdték az új állomány 12 hónapos alapkiképzését. A létszámcsökkentés kihatással volt a kiképzési modulok meghatározására, amely egyben a trénerek számának drasztikus csökkentéséhez vezetett. Az UPDF a találkozón támogatásáról biztosította a Mogadishuba települni szándékozó EUTM-S Összekötő Csoportját, amely támogatást a várakozásoknak megfelelően az AMISOM keretein belül fejtett ki. Spanyolország a továbbiakban nem vállalta a keretnemzeti feladatok ellátását, és felkérte az EUTM-S misszióban részt vevő nemzeteket, hogy intézkedjenek a felszerelések és a fegyverzeti anyagok hazaszállításáról. Azok őrzésére és tárolására az átmeneti időszakban nem volt további lehetőség, illetve Spanyolország elzárkózott más nemzet felszerelésének Madridba történő szállításától is. ${ }^{27}$

2013. január 22 -én életbe lépett az EU Tanácsának 2013/44/KKBP határozata az Európai Uniónak a szomáliai biztonsági erők kiképzéséhez hozzájáruló katonai missziójáról szóló 2010/96/KKBP határozat módosításáról és meghosszabbításáról. ${ }^{28}$ A 2013. szeptember 16-án Brüsszelben megtartott Szomáliával foglalkozó konferencián megszületett a Szomália-megállapodás, valamint létrejött a szomáliai New Deal munkacsoporton keresztül működő, a koordinációt és a szomáliai államépítés folytatását biztosító mechanizmus. ${ }^{29}$ 2013. szeptember 18-án az Egyesült Királyság és Szomália által közösen rendezett, Londonban tartott nemzetközi értekezleten az akkor már állandó struktúrákkal müködő Szomáli Szövetségi Kormány (Federal Government of Somalia, FGS) ismertette, hogy a védelmi minisztérium milyen módon kívánja fejleszteni 2019-ig az SNA erőit, illetve az azzal kapcsolatos igényeit. 2013. december 9-én a BTC-t bezárták és 2014. január 11-én az EUTM-S hivatalosan is átköltözött Mogadishuba. ${ }^{30}$

27 Interjú Kelemen Viktor őrnaggyal.

28 Council Decision 2013/44/CFSP of 22 January 2013 amending and extending Decision 2010/96/CFSP on a European Union military mission to contribute to the training of Somali security forces. [online], 2013. 01. 22. Forrás: eur-lex. europa.eu [2019. 04. 09.].

29 A New Deal for Somalia. [online], European Union External Action, 2013. 09. 16. Forrás: eeas.europa.eu [2019. 04. 09.].

30 Interjú Kelemen Viktor őrnaggyal., A European success story... EUTM Somalia magazine, July 2012. A szerző archívuma [2017.01.09.]. 


\section{Az EUTM-S mandátuma, feladatrendszere}

Az EUTM-S első mandátuma 2010. április 10-től 2011. június 31-ig datálódott. A miszszió első parancsnoka Ricardo González Elul spanyol ezredes volt. ${ }^{31}$ Az EUTM-S második mandátuma 2011. július 1-jétől tartott 2012. december 21-ig az ír szárazföldi erők delegáltja, Michael Beary ezredes parancsnoklásával. ${ }^{32}$ Ezen időszak alatt a fö feladat egy nagy létszámú kontingens alapkiképzése volt. Az EU a TFG számára az EUTM-S keretében évente $2 \times 6$ hónapos intervallumú időszakokban $2 \times 1000$ szomáli katona kiképzését vállalta. Ezek a katonák alkották a bázisát az ország újonnan felállítandó haderejének. 2013. január 1-jétől 2013. március 31-ig nem volt mandátuma az EUTM-S müveletnek, úgynevezett átmeneti időszak volt érvényben.

A katonai normáknak megfelelően az EUTM-S mandátumában foglalt feladatkörei alapján alakították ki a misszió szervezeti struktúráját (állománytábla) és a hatékony végrehajtást szolgáló eljárásrendjét. Az Észak-atlanti Szerződés Szervezete (North Atlantic Treaty Organization, NATO) nómenklatúrájának megfelelö törzselemek és biztosító alegységek mellett feladatának végrehajtása a Kiképző és Tanácsadó Csoportokon keresztül történt. A Kiképző Csoportot egy spanyol nemzetiségü ezredes vezette, a csoport tagjait a tagországok tiszt- és altisztállománya alkotta. Fő feladatuk az SNA kiképzése volt, amely a Mogadishuban, de a Mogadishui Nemzetközi Repülötér (Mogadishu International Airport, MIA) ${ }^{33}$ területén kívül eső Jazeera Kiképző Táborban (Jazeera Training Camp, JTC), illetve a Daghadaban Tábornok Kiképző Központban (General Daghadaban Training Centre, GDTC) zajlott. A Tanácsadó Csoportot a tagállamok fótiszt delegáltjai alkották egy olasz ezredes vezetése alatt. A tanácsadást és mentorálást a szomáliai védelmi minisztériumban, illetve a politikai elitnek otthont adó Villa Somalia palotában kezdték meg, ahol a vezérkar törzstisztjeit oktatták a vezetés-irányítás eljárásrendjeinek és törzskultúrájának eredményes kialakítása érdekében.

Az EUTM-S harmadik mandátuma Gerald Aherne és Massimo Mingiardi olasz dandártábornokok vezetése alatt zajlott 2013. április 1-jétől 2015. március 31 -ig. ${ }^{34} \mathrm{~A}$ harmadik mandátum alatt megújult a feladatrendszer és a struktúra; Ugandában a korábbi nagy létszámú alapkiképzést felváltotta a kisebb létszámú szakkiképzés (évi 300 fö), amelyen - elméletileg - már kiképzett, tapasztalt tisztek és altisztek vehettek részt. Ezek a katonák alkották a későbbiekben az SNA kiképzési rendszerének részét. Párhuzamosan a bihangai képzéssel Mogadishuban megkezdődött a Mentori, Tanácsadói és Speciális Kiképző Csoportok fokozatos kialakítása.

\footnotetext{
African Union: Green light for EU training mission to Somalia. [online], Forrás: africa-eu-partnership.org [2019. 04. 07.]. Irish colonel to head EU Somali mission. [online], 2011. 07. 26. Forrás: irishtimes.com [2019. 04. 07.].

Mogadishu International Airport (MIA): egy úgynevezett védett zóna, a repülőtér és azt körülvevő kb. 4 km²-es zárt zóna, amelynek területén belül maga a repülőtér, nemzetközi szervezetek (UNSOS, UNHCR, OCHA), nagykövetségek (olasz, brit, holland, svéd és az EU), az AMISOM bázisai, az EUTM-S, logisztikai bázisok, az ellátásban szerepet játszó civil cégek telephelyei, kisebb piacok, elárusító helyek és egyéb intézmények is találhatók. A védett zóna őrzését az AMISOM biztosítja. (A Szerző) 2017. 03. 18.

34 European Council: New Mission Commander for EU training mission in Somalia. [online], 2013. 12. 17. Forrás: consilium.europa.eu [2019. 04. 07.].
} 
Az EUTM-S negyedik mandátuma 2015. április 1-jétől tartott 2016. december 31-ig, parancsnoka az olasz Antonio Maggi dandártábornok volt. Maggi dandártábornokot a szintén olasz Maurizio Morena dandártábornok váltotta az EUTM-S 2017. január 1-jétől 2018. december 31-ig terjedö ötödik mandátuma alatt. ${ }^{35} \mathrm{~A}$ 4. és 5 . mandátum meghatározta a mentorálás, tanácsadás és speciális kiképzés végrehajtását Szomáliában.

A Tanács az EUTM-S hatodik mandátumát 2019. január 1-jétől kezdődően 2020. december 31-ig hosszabbította meg. A 6. mandátum alatt a parancsnoki beosztást elöször Matteo Giacomo Spreafico olasz dandártábornok töltött be, ${ }^{36}$ jelenleg pedig Antonello de Sio dandártábornok vezeti a missziót. ${ }^{37}$

Az EUTM-S feladatát összegezve egyértelmű prioritás a szomáliai biztonsági erők kiképzése. A misszió a kiképzés révén járult hozzá a TFG fegyveres erőinek képességalapú megszilárdításához, amely így elősegítette a fegyveres erők hatékony részvételét Szomália területi integritásának helyreállításában és az as-Sabáb terroristaszervezet általi fenyegetettség csökkentését célzó harcászati szintü müveletekben. A cél egy olyan kiképzett haderő létrehozása volt, amely képes garantálni a békét és a biztonságot, valamint a zavartalan gazdasági fejlődést az országban. Az EUTM-S mandátuma meghatározta, hogy a küldetés kiképzői csoportja vezetö- és szakkiképzésben nyújtson segítséget az SNA állományának, illetve adjon tanácsokat a Szomáliai Védelmi Minisztérium, valamint a Vezérkar részére. Emellett az EUTM-S továbbra is támogatta a szomáliai kiképzési rendszereket. ${ }^{38}$ Az EUTM-S mandátumából kifolyólag nem vett részt végrehajtói, harcászati szintű műveletekben.

Az MIA védőbástyáin kívüli kiképzési tevékenység kevésbé volt biztonságos. 2017. január 2-án óriási robbanás rázta meg a fövárost. A későbbi jelentésekből kiderült, hogy az as-Sabáb két gépjárműves öngyilkos merénylője hajtott végre támadást az MIA egyik bejárata mellett található rendőrségi ellenőrzö-áteresztő pontja, illetve az MIA területén kívül, közvetlenül a nemzetközi repülőtér termináljával szemben található Peace Hotel ellen, utóbbit teljesen elpusztította, és legkevesebb 30 áldozatot követelt. ${ }^{39}$

2017. április 10-én a terroristacsoport egyik öngyilkos merénylője - az SNA egyenruháját viselve - jutott át könnyedén a JTC biztonsági rendszerén és robbantotta fel magát, ami megölt legkevesebb kilenc fö kiképzendő SNA-katonát. Az eset után az EUTM-S parancsnoka ideiglenesen felfüggesztette a kiképzést. ${ }^{40}$

Az EUTM-S 2010 és 2018 között végrehajtott kiképzési eredményeit összegezve elmondható, hogy 5700 fő szomáli katonát képeztek az SNA számára, annak érdekében, hogy az SNA-t felállítsák és bevethető legyen a stabilitás és rend fenntartásában.

\footnotetext{
35 European Union External Action: New Commander of European Union training mission in Somalia. [online], 2016. 03. 21. Forrás: eeas.europa.eu [2019. 04. 07.].

36 European Council: Somalia: EU training mission extended, budget agreed and mandate amended. [online], 2018. 11. 19. Forrás: consilium.europa.eu [2019. 04. 09.].

37 European Union Training Mission Somalia: the Commander of CJTF-HOA visits EUTM Somalia Headquarters. [online], EUTM-Somalia, 2020. 06. 17. Forrás: eutm-somalia.eu [2020. 06. 24.].

38 European Council: Somalia: EU training mission extended, budget agreed and mandate amended (2018) i. m.

39 Massive blast hits near Mogadishu airport. [online], 2017. 01. 02. Forrás: aljazeera.com [2019. 01. 18.].

40 Soldiers killed in Somalia training camp suicide attack. [online], 2017. 04. 10. Forrás: aljazeera.com [2019. 04. 14.].
} 
A közel 100\%-os páratartalommal párosuló 35 fokos hőségben az EUTM-S kiképzőinek nem csupán a magas biztonsági kockázat általi veszélyeztetettséggel kellett szembenézniük. Kiképzésmódszertani oldalról vizsgálva kihívást jelentett a szomáli kiképzendők hiányos személyi felszerelése, adott esetben a lövészkiképzés elengedhetetlen kelléke, a gépkarabély. Az EUTM-S a fegyverek pótlását - ami nemzetközi jogilag is egy komplex kérdés - Hollandia segítségével oldotta meg, faanyagból készült és a szomáliai nemzeti lobogó égszínkék alapszínére mázolt kiképző-gépkarabélyok helyszínre szállításával. A kiképzés folytonosságát a rögtönzött megoldás képes volt szavatolni, de eredményessége szakmailag további kérdéseket vethetett fel. ${ }^{41} \mathrm{~A}$ spanyol kontingens 2018 februárjában katonai bakancsokat és egyéb felszereléseket adományozott az SNA kiképzendő állományának. ${ }^{42}$

2018. október 1-jén az EUTM-S egyik katonai menetoszlopát jármübe rejtett improvizált robbanóeszköz (Vehicle-born Improvised Explosive Device, VBIED) általi támadás érte. A merénylet során nem alakult ki tüzharc, nem kísérték a szokásos lövések, valamint az EUTM-S állományában nem történt sérülés. A jelentések szerint legkevesebb kettő fö szomáli polgár halt meg és további öt fö helyi lakos sérült meg a robbantás környezetében szétáramló repeszek hatására. ${ }^{43} 2019$. szeptember 30-án újabb VBIED-támadás érte az EUTM-S egyik katonai menetoszlopát a Szomáli Védelmi Minisztérium épületéhez közel. A merénylet során néhány szomáli civil és 1 fó olasz katona sérült meg. ${ }^{44} \mathrm{~A}$ robbantás érdekessége lehet, hogy a korábbi EUTM-S elleni támadás évfordulóján történt, valamint, hogy a szélsőséges milicisták a megelőző napon is végrehajtottak egy támadást az amerikai, a szomáli és az AMISOM-erőknek helyet adó egyik katonai bázis ellen. ${ }^{45}$

\section{Az EUTM-S magyar szerepvállalás}

Az EUTM-S magyar szerepvállalásának jogszabályi hátterét az 1100/2010. (IV. 28.) Kormányhatározat alapján látta el. ${ }^{46} \mathrm{~A}$ szerepvállalás hajnalán, 2010. február 23. és 2010. április 9. között az EUTM-S tervező törzse munkájának támogatása érdekében - Brüsszeli munkavégzésre - a misszió jogi tanácsadói (Legal Advisor, LEGAD) beosztásába kijelölt magyar törzstisztet útba indították. 2010. március 18-án Brüsszelben megrendezték az EUTM-S Többnemzeti Logisztikai Konferenciáját (Multinational Logistics Conference, MLC), amelyet a misszió akkori parancsnoka azzal a céllal hívott össze, hogy megegyezés

${ }_{41}$ Nederlands Detachement red the training van een Infanterie. [online], Uit \& Thuis Front, Koninklijke Luchtmatcht. Forrás: cgpagzrij.nl [2019. 04. 16.].

42 Spanish Contingent donated new boots and other personal supplies to Somali National Army attendees of the $1^{\text {st }}$ Light Infantry Company. [online], EUTM Somalia. 2018. 02. 18. Forrás: twitter.com [2019. 04. 16.].

43 Caleb Weiss: Shabaab targets Italian troops in Mogadishu with suicide bombing. [online], 2018. 10. 01. Forrás: longwarjurnal.org [2019. 04. 14.], EUTM-Somalia convoy hit in Mogadishu. [online], EUTM Somalia, 2018. 10. 01. Forrás: facebook.com [2019. 04. 14.].

44 Somalia - Suicide attack targets Italian troops in Mogadishu. [online], 2019. 09. 30. Forrás: arab24.com [2020. 06. 25.]; Arab24: Somalia - Suicide attack targets Italian troops in Mogadishu. [online], 2019. 09. 30. Forrás: youtube.com [2020. 06. 25.].

${ }_{45}$ Adbi Sheik: Twin Somali attacks hit U.S. special forces base, Italian convoy. [online], 2019. 09. 30. Forrás: reuters.com [2020. 06. 25.].

46 1100/2010. (IV. 28.) Korm. határozat Az Európai Uniónak a szomáliai biztonsági erők kiképzésére irányuló missziójához („EUTM Somalia”) történő magyar katonai hozzájárulásról. [online], Magyar Közlöny, (2010), 63. Forrás: kozlonyok.hu [2019. 04. 11.]. 
szülessen a szállítás és az egészségügyi biztosítás függőben lévő kérdéseiben. A megszületett döntés értelmében Spanyolország mint keretnemzet katonai szállító repülőgépeivel biztosította a törzs és a kiképzők Madridból az ugandai Entebbei Nemzetközi Repülőtérre való kiszállítását. Az USA vállalta a misszió állományának Entebbéből Kampalába és a kiképzői állomány Kampalából Bihangába történő szállítását. A parancsnokságot és a törzs (25 fö) állományát egy kampalai hotelben helyezték el. Ennek költsége 40 ezer EUR/hó volt, ezen felül az étkezésekre 25 EUR/fö/nap költséget számoltak fel. A BTC-ben a kiképzők teljes ellátási költsége 38,08 EUR/fö/nap volt. A kiképzőknek a szállásért nem kellett fizetniük. ${ }^{47}$

2010. április 22-én a LEGAD és a kiképző csoport AN-26 típusú szállító repülőgéppel Madrid-Torrejón repülőtérre utaztak. Lőszer-javadalmazásuk 500 db 9 mm-es pisztolylőszer volt. 2010. április 23-án az esti órákban a négyfös magyar kontingenst telepítették Ugandába a madridi Barajas repülőtérről. A következő napon, 2010. április 24-én a magyar kiképzők megérkeztek Kampalából a BTC-be. ${ }^{48}$

2010. szeptember 10-én az EU által médialátogatást szerveztek Bihangába. Magyarországról a csoport tagjaként jelen volt Gergely Márton, a Népszabadság újságírója. A látogatásról készített cikke 2010. október 16-án jelent meg a Népszabadság Hétvége mellékletében, A túlélés joga címmel ${ }^{49} 2010$. november 15. és november 22 . között Hettyey András doktori disszertációjának - Szomália és a kelet-afrikai országok regionális biztonsági komplexitása - megírásához végzett helyszíni kutatást Ugandában, szintén az EUTM-S parancsnokának engedélyével. ${ }^{50}$

2011. március 1-jén az EUTM-S magyar vonatkozású ügyintézése átkerült a Székesfehérvárott települt $\mathrm{MH}$ Összhaderőnemi Parancsnokság ( $\mathrm{MH}$ ÖHP) alárendeltségébe a budapesti székhelyű Műveletirányító Központ felelősségi köréből. 2011. június 17-én az MH ÖHP parancsnokának döntése alapján a misszióban szolgáló 4 fö magyar katona közül az alapkiképzési modul befejeztével 3 föt polgári repülőjárattal kivontak a müveleti területről. Felszerelésüket, fegyvereiket és a lőszerkészleteiket átadták a misszió törzsében szolgálatot teljesítő LEGAD részére. A LEGAD-ot az összes felszereléssel 2011. június 22-én, amerikai légihíddal, Ramstein légitámaszponton keresztül telepítették volna haza Magyarországra, azonban a Honvéd Vezérkarfönök helyettese levelében intézkedett a LEGAD, valamint a részére kiadott fegyver és felszerelés müveleti területen tartására. 2012. december 13-án Michael Beary ezredes, a misszió akkori parancsnoka felkérte hazánkat, hogy a január és március közötti átmeneti időszakra is biztosítsa a jogász törzstisztet, mivel a misszió átalakítása szempontjából kiemelt fontosságú az általa végzett feladat. A törzstiszt többnyire Kampalában dolgozott, de néhány esetben, hosszabb-rövidebb időre Szomáliába utazott. A Honvéd Vezérkarfőnök helyettese következő levelében hozzájárult a fentiek ellátáshoz és az állomány megkezdte a feladat-végrehajtást. ${ }^{51}$

47 Interjú Kelemen Viktor őrnaggyal; Interjú az MH ÖHP BMF afrikai külszolgálatokért felelős blokkjának törzstisztjével. 2018. 12. 10 .

48 Besenyő János: Magyar kiképzők az Európai Unió Szomáliai Kiképző Missziójában. [online], 2011. 01. 01. Forrás: researchgate.net [2019.04.09.].

49 A túlélés joga. [online], Népszabadság, 68. (2010), 242. Forrás: arcanum.hu [2019. 04. 09.].

50 Hettyey András: Living with a failed State: Somalia and the States of the East African Regional Security Complex 2009-2011. [online], 2011. Forrás: real-phd.mtak.hu [2019. 04. 09.].

51 Interjú Kelemen Viktor őrnaggyal. 
2012. december 20. és december 23. között a szolgálati idejének lejáratával a magyar kiképzőcsoport elhagyta a misszió műveleti területét. ${ }^{52} \mathrm{~A}$ szállítást egy, az entebbei katonai repülőtérről induló amerikai C-130-as szállító repülőgép végezte, Dzsibuti-Kréta-Stuttgart útvonalon, az utolsó, Stuttgart-Budapest-Kaposvár szakaszon MH támogatással. A kalandos visszatelepülés három és fél napot vett igénybe. Az utazás a körülményekhez képest az amerikai hadsereg Dzsibutiban állomásozó összekötő tisztjének, valamint a C-130-as személyzetének köszönhetően zökkenőmentesen zajlott. Dzsibutiban a helyi hatóságok addig nem engedték ki az állományt az országból, amíg a vízumot meg nem fizették, ami fejenként 60 amerikai dollárt jelentett, és azt az amerikai hadsereg előlegezte meg a reptéren. Krétán a szállító repülőgép műszaki okok miatt egy teljes napot vesztegelt, így az állomány az éjszakát az ott állomásozó amerikai haditengerészeti bázis túltelítettsége okán, az amerikai fél iránymutatása alapján egy helyi szállodában töltötte. ${ }^{53}$

2013. december 30-án a LEGAD, egy kiképző altiszt, egy szerb orvos és egy portugál felderítő társaságában áttelepült Mogadishuba, az EUTM-S táborába. A következő napokban az EUTM-S maradék állománya is elhagyta a kampalai bázist. Az áttelepülést rendben végrehajtották. A kiutalt személyi felszerelés, fegyverzet, az átvett anyagokkal együtt biztonságban az új szolgálati helyükre érkeztek. Az MIA területén lévő EUTM-S nemzetközi táborban (International Campus, IC) az állomány elöször ideiglenes konténerszállásba, majd három nappal később újonnan épített téglaépületbe költözött. ${ }^{54}$

2014. január 1-jén az MIA területén elhelyezkedő ENSZ-ügynökségek és az EUTM-S tábora ellen a hajnali órákban aknagránát-támadást hajtottak végre. A későbbi jelentésekből kiderült, hogy hat gránátot lőttek ki, amelyek közül egy okozott anyagi kárt az IC-vel szomszédos ENSZ-táborban (megrongált egy konténert), és kettő csapódott be az EUTM-S táborának közvetlen közelében. A gránátok sérülést, halált nem okoztak. Szintén ennek a napnak az estéjén az MIA bejáratától csupán 300 méterre fekvő Jazeera Hotel előtt 19:50-kor és 20:50-kor is gépkocsiba rejtett pokolgépek robbantak, 11 halottat és 40 sérültet hagyva maguk után. ${ }^{55}$

2014. január 10-én az utolsó magyar altiszt is elhagyta Kampalát, és hazatért Magyarországra. Ezzel hazánk befejezte az EUTM-S ugandai műveleti területén a szolgálatteljesítést. A zászlóst az EUTM-S állományában végzett kiemelkedő munkája elismeréseként a külszolgálat befejezése alkalmából az MH ÖHP parancsnoka 2014. január végén elismerésben részesítette. ${ }^{56}$

A magyar katonák kiképzői feladatairól a fentiekben már tettem említést, érdemes azonban röviden összefoglalni a LEGAD és a logisztikus altiszt beosztottak feladatkörét is. A LEGAD jogi kérdésben nyújtott tanácsadást a misszió parancsnokának és törzsének,

52 Magyar Honvédség: Magyar segitséggel képzik Ugandában a szomáliai katonákat. [online], Forrás: facebook.com [2019. 04. 09.], Új magyar rangidös nemzeti képviselö az EUTM-misszióban. [online], 2012. 03. 12. Forrás: honvedelem. hu [2019. 04. 09.]; Ünnep és medálparádé az EUTM Somalia misszióban. [online], 2012. 12. 12. Forrás: honvedelem.hu [2019. 04. 09.]

53 Lezárult a második fázis az ugandai kiképzésben. [online], 2012. 11. 07. Forrás: honvedelem.hu [2019. 04. 09.]; Barczikay Tamás: Dzsibuti stratégiai fekvése: áldás vagy átok? [online], 2020. 06. 24. Forrás: afrikablog.hu [2020. 06. 25.]

54 Interjú Kelemen Viktor örnaggyal.

55 Hotel in Somali capital Mogadishu hit by car bombs. [online], 2014. 01. 01. Forrás: bbc.com [2019. 04. 10.]

56 Interjú Kelemen Viktor őrnaggyal.; Interjú az MH ÖHP BMF afrikai külszolgálatokért felelős blokkjának törzstisztjével. 2018. 12. 10 . 
illetve összekötőtiszti feladatokat látott el az ugandai-szomáliai hadsereg és a misszió parancsnoksága között. Időszakos előadások megtartásával a LEGAD is érintett volt a szomáli katonák kiképzésében. A logisztikai altiszt beosztottak a logisztikai tiszt irányítása alatt tevékenykedtek; közlekedés/szállítás tervezése-szervezése, koordinálása, szállással, elhelyezéssel kapcsolatos feladatok végzése, valamint szerződött szolgáltatókkal való kapcsolattartás jelentette mindennapi szolgálati feladataikat. ${ }^{57}$

\section{4-2019}

2014. január 11-én az EUTM-S misszió hivatalosan is átköltözött Ugandából Szomáliába, Mogadishuba, az MIA területére. Ami a vizsgált időszak magyar szerepvállalását illeti, 2015. május 1-jével a magyar hozzájárulás nemzetközi nyomásra átalakult, és a mentorok helyett logisztikai altiszt beosztottakat telepítettek ki. 2017. március 31-i hatállyal a LEGAD-beosztást lemondták, ezzel dr. Kelemen László önkéntes műveleti tartalékos örnagy ${ }^{58}$ kétéves szomáliai kiküldetése is véget ért. A törzstiszti kvótát felhasználva Magyarország 2017. április 16-tól vezényelt tiszteket a Mission Commander-i iroda Aide de Camp (parancsnoki segítő) beosztásába. ${ }^{59} \mathrm{~A}$ parancsnoki segítő beosztás feladata volt többek között a Mission Commander utazásainak tervezése-szervezése, magas rangú látogatások tervezése-szervezése, a vendégek köszöntése a misszió parancsnokának nevében, szervezni és biztosítani a napi életet a parancsnoki irodán, menedzselni a parancsnok levelezéseit és további, a törzs irányába tett írásos parancsait, intézkedéseit, valamint támogatni a misszió parancsnokát az adminisztráció egyéb területein. ${ }^{60}$

Az EU Tanácsa 2015. március 16-án fogadta el 2015/441/KKBP határozatát, ${ }^{61}$ és 2016. december 12-én a 2016/2239/KKBP határozatát az Európai Uniónak a szomáliai biztonsági erők kiképzéséhez hozzájáruló katonai missziójáról szóló 2010/96/KKBP határozat módosításáról és meghosszabbításáról. ${ }^{62} \mathrm{Az}$ EU Tanácsa 2018. november 19-én elfogadott és érvényben lévő 2018/1787/KKBP határozata alapján a misszió mandátumát 2020. december 31-ig hosszabbította meg. ${ }^{63}$

Az EUTM-S Mogadishuba történő áthelyezését követően Olaszország látta el a keretnemzeti feladatokat, és további tíz EU-s tagország - Franciaország, Finnország, Hollandia, Magyarország, Egyesült Királyság, Németország, Portugália, Románia, Spanyolország, Svédország - és Szerbia mint harmadik fél részvételével folytatódott a szerepvállalás. Szerbia

57 Kelemen László: Hungarian Participation in the European Union Training Mission Somalia. [online], Defence Review, (2017), 2. 2018. 04. 03. Forrás: honvedelem.hu [2019. 03. 13.].

58 A szomáliai misszió jogi szemmel. [online], 2016. 09. 26. Forrás: honvedelem.hu [2019. 04. 11.].

59 Kelemen (2017) i. m.

60 EUTM-S Aide de Camp job specification. Nyílt, 1 oldal. A szerző archívuma. [2017. 01. 17.].

61 Council Decision (CFSP) 2015/441 of 16 March 2015 amending and extending Decision 2010/96/CFSP on a European Union military mission to contribute to the training of Somali security forces. [online], 2015. 03. 16. Forrás: eur-lex. europa.eu [2019. 04. 14.].

62 A Tanács (KKBP) 2016/2239 határozata (2016. december 12.) az Európai Uniónak a szomáliai biztonsági erők kiképzéséhez hozzájáruló katonai missziójáról szóló 2010/96/KKBP határozat módosításáról és meghosszabbításáról. [online], 2016. 12. 12. Forrás: eur-lex.europa.eu [2019. 04. 14.].

63 A Tanács (KKBP) 2018/1787 határozata (2018. november 19.) az Európai Uniónak a szomáliai biztonsági erők kiképzéséhez hozzájáruló katonai missziójáról szóló 2010/96/KKBP határozat módosításáról és meghosszabbításáról. [online], 2018. 11. 19. Forrás: eur-lex.europa.eu [2019. 04. 14.]. 
egészségügyi csoporttal (Role-1 képesség) járult hozzá az EU mindhárom afrikai kiképző missziójához. Ekkor az EUTM-S éves költségvetése 19,7 millió euró volt, valamint 195 fö katona alkotta a misszió létszámát. ${ }^{64}$ 2019-ben a misszió 6. mandátuma alatt az éves költségvetés 11,4 millió euróra zsugorodott, mialatt a misszió létszáma közel azonos maradt (203 fö). Ugyanakkor időközben négy tagország - Franciaország, Hollandia, Németország és Magyarország - is kivonta erőit. ${ }^{65}$

Ami a magyar katonák kivonását illeti, a minisztertől kapott felhatalmazása alapján az MH ÖHP parancsnoka intézkedett a magyar szerepvállalás szomáliai felszámolásáról, vagyis az EUTM-S műveletében szolgáló magyar állomány és technikai eszközök műveleti területről történő kivonásának előkészítéséről és végrehajtásáról. A kivonás előkészítésének és végrehajtásának koordinálását az MH ÖHP Békemüveleti Főnökség (MH ÖHP BMF) végezte. Az MH ÖHP parancsnokának parancsa értelmében a kivonásig Magyarország a mủveleti területen való tartózkodással kapcsolatban általános érvényủ nemzeti korlátozást nem vezetett be, azonban minimum 72 órával a tervezett vidéki utazások elött a nemzeti rangidős útján tájékoztatást kért, hogy a szükséges biztonsági elemzéseket meg tudja tenni.

A kivonás tervezett ütemének megfelelően - a négy fő magyar katonából - három főt 2018. december 31-én vontak ki polgári járattal, egy föt pedig tervezetten 2019. január 1-je és 15-e között az MH ÖHP Logisztikai Mủveleti Főnökség (MH ÖHP LMF) által szervezett légihíddal. A fegyverek és lőszerek légihídon - honi területre - történő szállítása során a szállítmánykísérői feladatokat a kijelölt altiszt hajtotta végre. Egy szük évtizedet - a 2010. április 7-ei ugandai első kihelyezést - követően 2019. február 25-én az utolsó magyar katona is elhagyta az EUTM-S müveleti területét. ${ }^{66}$

A magyar kivonulás kapcsán a biztonságpolitikai tényezőket is érdemes megvizsgálni. A magyar biztonságpolitikai elvek számos esetben lekövetik a német biztonságpolitikát. Ez különösen igaz az olyan esetekben, amikor döntési kényszer alatt a magyar diplomácia nem rendelkezik megfelelő szakmai információval az adott térségről vagy a regionális viszonyokról, ebből kifolyólag célszerűbb követnie a német döntéshozókat.

A napjainkban virágzó német-magyar katonai együttmüködés komoly múltra tekint vissza. A NATO afganisztáni szerepvállalása kapcsán érdemes kiemelni, hogy 2004. március 30-án 3 fö magyar törzstisztet és 7 fö tiszthelyettest vezényeltek és telepítettek ki a Nemzetközi Biztonsági Közreműködő Erő (International Security Assistance Force, ISAF) V. keretén belül, a német vezetésü, Kunduz városában települt Tartományi Ujjáépítési Csoportba (Provincial Reconstruction Team, PRT). ${ }^{67}$

A szerepvállalás történelmi súlyát fémjelzi, hogy az ISAF V. műveletbe vezényelt magyar katonák Budapesten (Stefánia Palota) megrendezett kibocsátó ünnepségén a Honvédelmi Minisztérium (HM) politikai államtitkára és a Honvéd Vezérkar főnökének helyette-

64 European Union Training Mission - Somalia: Factsheet. Updated: April 2016. [online], European Union External Action, 2016. 04. 01. Forrás: eeas.europa.eu [2019. 04. 14.].

${ }^{65}$ European Union Training Mission - Somalia: Factsheet. Updated: January 2019. [online], EUTM-Somalia, 2019. 01. 01. Forrás: eutm-somalia.eu [2019. 04. 14.].

66 Interjú Kelemen Viktor örnaggyal.

67 Isaszegi János: A honvédség részvétele a nemzetközi békemüveletekben - Tények, lehetöségek, tapasztalatok. [online], 2005. 12. 01. Forrás: mhtt.eu [2019.03. 12.]. 
se mellett részt vett a Német Szövetségi Köztársaság Védelmi Minisztérium Müveleti Parancsnokságának képviseletében dr. Ingo Patschke orvos ezredes is. ${ }^{68}$

A német-magyar szál tovább erősödött az afganisztáni Baghlan tartományba települt magyar vezetésü PRT müködése során - 2006-2013. év között -, ahol mindvégig német parancsnokság alatt látta el feladatát a komplex müveleti környezetben. ${ }^{69}$ Érdemes megemlíteni a magyar-német katonai együttmüködés kapcsán a közelmúlt eseményeit is. A Honvédelmi és Haderőfejlesztési Program keretében Magyarország 2018. december 19-én német haditechnikai eszközök beszerzéséről szóló szerződést írt alá a HM-ben. ${ }^{70}$ Figyelembe véve tehát a gyümölcsöző magyar-német katonai kapcsolatokat a Bundeswehr 2018. március végi szomáliai csapatkivonásának racionális külpolitikai töltete lehetett a magyar fél számára is. ${ }^{71}$

Az EUTM-S müveletből a magyar erők kivonásával párhuzamosan az $\mathrm{MH}$ növelte szerepvállalását a 2013. év óta mandátummal rendelkező Európai Unió Mali Kiképző Missziója (European Union Training Mission in Mali, EUTM Mali) missziójában, 7 fó katonáról 21 före. Kétségtelen hozadékkal jár az MH számára, hogy Magyarország az EU afrikai müveleteibe tett felajánlását Malira összpontosította; költséghatékonyabb logisztikai-támogatási rendszer, célirányosabb kiképzés és felkészítés, hatékonyabb küldetésorientált végrehajtás, valamint jelentősebb külpolitikai és nemzeti érdek valósulhatnak meg. ${ }^{72}$ A német-magyar biztonságpolitikai együttmüködés szempontjából nem mellékes tényező, hogy az elmúlt években Németország Franciaországot támogatva fokozottabban vesz részt a Maliban zajló ENSZ- és EU-müveletekben, ebből kifolyólag kézenfekvő lehet a magyar biztonságpolitikának is követnie a német-francia stratégiai irányt. ${ }^{73}$

A magyar kivonulás kapcsán az MH EU-s müveleteinek centralizálása, valamint a fragmentáció megszüntetése bizonyul még jelentős döntési pontnak. Az MH szerepvállalását

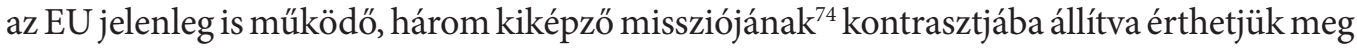
könnyebben. Az EU 2016. év óta müködő Közép-afrikai Köztársaság Kiképző Missziójába ez idáig nem került magyar felajánlás. Annak ellenére sem történt ez meg, hogy a Középafrikai Köztársaságban ENSZ-keretek által müködtetett Közép-afrikai Köztársaságbeli Többdimenziós Integrált Stabilizációs Misszióba (United Nations Multidimensional

68 Az ISAF V. kiutazó állomány búcsúztatása. A szerző archívuma. [2004. 03. 26.].

69 Gazdag Ferenc: A magyar külpolitika 1989-2014. Budapest, Nemzeti Közszolgálati Egyetem, 2014.

70 A szerződést Ralf Ketzel, a Krauss-Maffei Wegmann ágazati igazgatója, Holger Lenz, a Krauss-Maffei Wegmann vállalatcsoport ágazati kereskedelmi igazgatója, és Fodor Péter, a HM Védelemgazdasági Hivatalának főigazgatója írta alá, amelynek értelmében 44 darab új Leopard 2 A7+ típusú harckocsi és 24 darab PzH 2000 típusú önjáró löveg beszerzéséröl állapodtak meg. A technikai eszközök megvásárlásával és rendszerbe állításával az MH harcászati és hadmüveleti képességei a 21. századi hadviselés követelményeinek megfelelően növekednek, amelyek egyaránt alkalmazhatóak a hagyományos és az aszimmetrikus hadviselésben. Lásd: Új harckocsikat vesz a honvédség. [online], 2018. 12. 19. Forrás: honvedelem.hu [2019. 03. 12.].

71 Daily Sabah: German military ends mission in Somalia after 8 years. [online], 2018. 04. 03. Forrás: dailysabah.com [2019. 03. 12.].

72 Interjú az MH ÖHP BMF afrikai külszolgálatokért felelős blokkjának törzstisztjével. 2018. 12. 10.

73 DW: Germany extends Bundeswehr mission in Mali. [online], 2020. 05. 29. Forrás: dw.com [2020. 10. 08.].

74 European External Action Service: Military and civilian missions and operations. [online], 2019. 03. 05. Forrás: eeas. europa.eu [2019. 03. 12.]. 
Integrated Stabilization Mission in the Central African Republic, MINUSCA) hazánk 4 fö kéksapkással képviseltette magát 2019. június 30-ig. ${ }^{75}$

\section{Összegzés}

A Szomáli Szövetségi Kormány megfelelő biztonságágazati politikai háttér és a lakosság megnyerése nélkül nem rendelkezik elégséges támogatottsággal, fennmaradása az AMISOM esetleges távozása után ilyen szempontból is kétséges. Ez azért is érdekes, mert a szomáli kormány eszmei háttere lényegében nem különbözik az as-Sabáb iszlamista hátterétől: mindkét formáció a saría szabályait követi, valamint Szomália alkotmányának 2. cikkelye jelenleg is elöírja, hogy Szomália államvallása az iszlám. ${ }^{76} \mathrm{Az}$ alapvetö különbség csak az, hogy a jelenlegi kormány együttműködik a nemzetközi közösséggel, míg az asSabáb nem. Az as-Sabáb szervezetének nincs globális terrorista ambíciója és képessége, csupán regionális érdeklődése van. A nemzeti mozgalom jellegét támasztja alá az is, hogy nem vált az Iszlám Állam szövetségesévé, annak ellenére sem, hogy voltak ilyen kísérletek.

A fentiek értelmében felmerül a kérdés, hogy mit is keres egy maroknyi európai kontingens az MIA kifutópályája körüli talpalatnyi, betonfalakkal övezett védett zónájában a világ egyik legszegényebb és egyben legveszélyesebb afrikai országában? Az EUTM-S tagjai tudatában vannak annak, hogy az európai érdekeket szolgálják a fekete kontinensen. Célkitűzésük, hogy a kiképzésen és tanácsadáson keresztül megerősítsék a szomáliai biztonsági erőket, amelyek ezáltal képesek lesznek segíteni a kormányt hatalmának gyakorlásában és a biztonság fenntartásában. A távlati cél pedig az, hogy az SNA képes legyen az as-Sabáb térnyerésének önálló megfékezésére, egyidejüleg a nemzetközi aktorok folyamatos kivonásával. A biztonsági apparátus megerősítésével visszaszorítható lehetne a megélhetési bűnözés és az illegális migráció, megóvva ezzel többek között Európa társadalmait.

A kutatómunka rávilágít arra is, hogy az afrikai klánizmus alapjaiban ássa alá a szomáli államépítést. Az EU sokéves erőfeszítései ellenére az SNA továbbra sem képes szavatolni a békét és a biztonságot, elsősorban a korrupció és a klánizmus miatt, amely gyengíti az as-Sabáb elleni fellépés egységét. ${ }^{77}$

Az EUTM-S állományának a 21. század komplex müveleti környezetében kell mindennapi harcukat megvívniuk. Abban a sokrétű műveleti környezetben, ahol a katonai feladatok tervezése-szervezése és végrehajtása során egyaránt számolni kell a fizikai, a humán, a klimatikus és a közpolitikai környezet, valamint a koppenhágai iskola teoretikusai által megalkotott biztonságiasítás szegmenseinek valamennyi tényezőjével. A folyton változó körülmények jelenségeinek sajátos összetettsége eredményezi Afrika szarvának biztonságpolitikai komplexitását, ezt a zéró végösszegü játékot, amelynek kifutása továbbra is bizonytalan. $^{78}$

\footnotetext{
5 Facts and Figures; Millitary strength summary. [online], Forrás: minusca.unmissions.org [2019. 03. 12.].

76 Marsai Viktor: Szomália: Államépítés és nomád klánállam Afrika szarván - Percepció, transzformáció és stratégiai kényszerek. [online], NKE SVKK - Elemzések, (2015), 1. Forrás: grotius.hu [2019. 04. 16.].

77 Marsai (2020) i. m.

78 Az én felderítö történetem - 100 éves az önálló magyar katonai felderités, hírszerzés és kémelhárítás. Budapest, Felderítők Társasága Egyesület. 2018. [online], Forrás: knbsz.gov.hu [2019. 04. 18.].
} 


\section{FELHASZNÁLT IRODALOM}

2011 Failed States Index Released: Somalia ranked most troubled state; Finland takes best position. [online], 2011. 06. 20. Forrás: reliefweb.int [2019. 03. 13.]

A European success story... EUTM Somalia magazine, July 2012. A szerző archívuma. [2017. 01. 09.].

African Union: Green light for EU training mission to Somalia. [online], Forrás: africa-eu-partnership.org [2019. 04. 07.]

Arab24: Somalia - Suicide attack targets Italian troops in Mogadishu. [online], 2019. 09. 30. Forrás: arab24.com [2020. 06. 25.]

Az én felderitö történetem - 100 éves az önálló magyar katonai felderités, hírszerzés és kémelháritás. Budapest, Felderítők Társasága Egyesület. 2018. [online], Forrás: knbsz.gov.hu [2019. 04. 18.]

A túlélés joga. [online], Népszabadság, 68. (2010), 242. Forrás: arcanum.hu [2019. 04. 09.]

Barczikay Tamás: Dzsibuti stratégiai fekvése: áldás vagy átok? [online], 2020. 06. 24. Forrás: afrikablog.hu [2020. 06. 25.]

Battle of Mogadishu (1993) - Black Hawk Down. [online], Forrás: militaryfactory.com [2019. 03. 13.]

Besenyő János: Magyar kiképzők az Európai Unió Szomáliai Kiképző Missziójában. [online], 2011. 01. 01. Forrás: researchgate.net [2019.04.09.]

Biedermann Zsuzsánna: Genocídium és destabilizáció az afrikai nagy tavak régióban. A konfliktus gazdasági vetülete. Budapest-Pécs, IDResearch Kft. - Publikon, 2015.

DW: Germany extends Bundeswehr mission in Mali. [online], 2020. 05. 29. Forrás: dw.com [2020. 10. 08.]

European Council: New Mission Commander for EU training mission in Somalia. [online], 2013. 12. 17. Forrás: consilium.europa.eu [2019. 04. 07.]

European Council: Somalia: EU training mission extended, budget agreed and mandate amended. [online], 2018. 11. 19. Forrás: consilium.europa.eu [2019. 04. 09.]

European External Action Service: Military and civilian missions and operations. [online], 2019. 03. 05. Forrás: eeas.europa.eu [2019. 03. 12.]

European Union External Action: New Commander of European Union training mission in Somalia. [online], 2016. 03. 21. Forrás: eeas.europa.eu [2019. 04. 07.]

European Union Training Mission - Somalia: Factsheet. Updated: April 2016. [online], European Union External Action, 2016. 04. 01. Forrás: eeas.europa.eu [2019. 04. 14.]

European Union Training Mission - Somalia: Factsheet. Updated: January 2019. [online], EUTM-Somalia, 2019. 01. 01. Forrás: eutm-somalia.eu [2019. 04. 14.]

European Union Training Mission Somalia: the Commander of CJTF-HOA visits EUTM Somalia Headquarters. [online], EUTM-Somalia, 2020. 06. 17. Forrás: eutm-somalia.eu [2020. 06. 24.]

EUTM-S Aide de Camp job specification. Nyílt, 1 oldal. A szerző archívuma. [2017. 01. 17.]

EUTM-Somalia convoy hit in Mogadishu. [online], EUTM Somalia, 2018. 10. 01. Forrás: facebook.com [2019. 04. 14.] United Nations Multidimensional Integrated Stabilization Mission in the Central African Republic (MINUSCA): Facts and Figures; Millitary strength summary. [online], Forrás: minusca.unmissions.org [2019. 03. 12.]

The Fund for Peace: Failed States Index 2013: The Troubled Ten. [online], 2013. 06. 24. Forrás: fundforpeace. org [2019. 03. 13.]

The Fund for Peace: Fragile States Index 2016 - Annual Report. [online], 2016. 06. 27. Forrás: fragilestatesindex. org [2019. 03. 13.]

The Fund for Peace: Fragile States Index 2018: Issues of Fragility Touch the World's Richest and Most Developed Countries in 2018. [online], 2018. 04. 19. Forrás: fragilestatesindex.org [2019. 03. 13.]

Gazdag Ferenc: A magyar külpolitika 1989-2014. Budapest, Nemzeti Közszolgálati Egyetem, 2014.

German military ends mission in Somalia after 8 years. [online], Daily Sabah, 2018. 04. 03. Forrás: dailysabah. com [2019. 03. 12.]

Hansen, Stig Jarle: Al-Shabaab in Somalia. The History and Ideology of a Militant Islamist Group. London, C. Hurst \& Co. (Publishers) Ltd. 2016. 
Hettyey András: Living with a failed State: Somalia and the States of the East African Regional Security Complex 2009-2011. [online], 2011. Forrás: real-phd.mtak.hu [2019. 04. 09.] DOI: https://doi.org/10.15772/ ANDRASSY.2011.003

Hotel in Somali capital Mogadishu hit by car bombs. [online], 2014. 01. 01. Forrás: bbc.com [2019. 04. 10.]

Interjú az MH ÖHP BMF afrikai külszolgálatokért felelős blokkjának törzstisztjével. 2018. 12. 10.

Interjú Kelemen Viktor őrnaggyal az MH Parancsnoksága, Hadmüveleti Csoportfőnökség, Müvelettervező Főnökség, Szárazföldi Műveleti blokk törzstisztjével (MH ÖHP BMF afrikai külszolgálatokért felelős blokkjának volt törzstisztjével). 2019. 03. 01.

Irish colonel to head EU Somali mission. [online], 2011. 07. 26. Forrás: irishtimes.com [2019. 04. 07.]

Isaszegi János: A honvédség részvétele a nemzetközi békemüveletekben - Tények, lehetöségek, tapasztalatok. [online], 2005. 12. 01. Forrás: mhtt.eu [2019. 03. 12.]

Íme, a magyar kormány Afrika-stratégiája: segély, export, katonák és mintafarmok. [online], 2019. 04. 02. Forrás: hvg.hu [2019. 04. 18.]

Kelemen László: Hungarian Participation in the European Union Training Mission Somalia. [online], Defence Review, (2017), 2. 2018. 04. 03. Forrás: honvedelem.hu [2019. 03. 13.]

Kelemen László: A szomáliai misszió jogi szemmel. [online], 2016. 09. 26. Forrás: honvedelem.hu [2019. 04. 11.]

Lezárult a második fázis az ugandai kiképzésben. [online], 2012. 11. 07. Forrás: honvedelem.hu [2019. 04. 09.]

Local ownership. [online], Forrás: interpeace.org [2020. 03. 17.]

Magyar Honvédség: Magyar segítséggel képzik Ugandában a szomáliai katonákat. [online], Forrás: facebook. com [2019. 04. 09.]

Marsai Viktor: Főnixmadár Afrika szarván - az as-Sabáb tevékenysége 2015-2017. Budapest, Nemzeti Közszolgálati Egyetem. 2020a.

Marsai Viktor: Az Öböl-államok szerepe Kelet-Afrikában. Marsai Viktor habilitációs eljárásának nyilvános vitája és előadása. PowerPoint előadás (28 dia). 2020b.

Marsai Viktor: Szomália: Államépítés és nomád klánállam Afrika szarván - Percepció, transzformáció és stratégiai kényszerek. [online], NKE SVKK - Elemzések, (2015), 1. Forrás: grotius.hu [2019. 04. 16.]

Massive blast hits near Mogadishu airport. [online], 2017. 01. 02. Forrás: aljazeera.com [2019. 01. 18.]

Ministero della Difesa: Somalia - UNOSOM „Ibis”. [online], Forrás: esercito.difesa.it [2019. 03. 13.]

Nagy Sándor: Hogyan tovább Szomália? [online], 2017. 01. 11. Forrás: afrikablog.hu [2019. 03. 13.]

Nederlands Detachement red the training van een Infanterie. [online], Uit \& Thuis Front, Koninklijke Luchtmatcht. Forrás: cgpagzrij.nl [2019. 04. 16.]

A New Deal for Somalia. [online], European Union External Action, 2013. 09. 16. Forrás: eeas.europa.eu [2019. 04. 09.]

Oluoch, Fred: Somalia's federal states gang up against Farmajo. [online], 2018. 09. 08. Forrás: theeastafrican. co.ke [2019. 04. 07.]

Pusztai Dávid: A szomáliai kísérlet. Az ENSZ Biztonsági Tanácsának útkeresése a hidegháború utáni új világrendben. Budapest, Gondolat, 2015.

Republic of Turkey Ministry of Foreign Affairs: The Second Istanbul Conference on Somalia, Final Declaration, 1 June 2012, Istanbul. [online], 2012. 06. 01. Forrás: mfa.gov.tr [2019. 04. 09.]

Sheik, Adbi: Twin Somali attacks hit U.S. special forces base, Italian convoy. [online], 2019. 09. 30. Forrás: reuters. com [2020. 06. 25.]

Soldiers killed in Somalia training camp suicide attack. [online], 2017. 04. 10. Forrás: aljazeera.com [2019. 04. 14.] Somalia - Suicide attack targets Italian troops in Mogadishu. [online], 2019. 09. 30. Forrás: youtube.com [2020. 06. 25.] Spanish Contingent donated new boots and other personal supplies to Somali National Army attendees of the $1^{\text {st }}$ Light Infantry Company. [online], EUTM Somalia. 2018. 02. 18. Forrás: twitter.com [2019. 04. 16.]

United Nations Security Council: Statement by the President of the Security Council. [online], 2009. 12. 03. Forrás: undocs.org [2019. 04. 07.]

The Foreign Policy: The 2009 Failed States Index. [online], 2009. 06. 21. Forrás: foreignpolicy.com [2019. 03. 13.]

The Foreign Policy: The Failed States Index 2010. [online], 2010. 06. 17. Forrás: foreignpolicy.com [2019. 03. 13.]

The Fund for Peace: The Failed States Index 2012. [online], Forrás: reliefweb.int [2019. 03. 13.] 
United Nations Security Council: UNHCR Resolution 1872: The situation in Somalia. [online], 2009. 05. 26. Forrás: unscr.com [2019. 04. 07.]

United Nations Operation in Somalia (UNSOM). [online], Forrás: unsom.unmission.org [2019. 03. 13.]

United Nations Security Council: Report of the Secretary-General on Somalia. [online], 2011. 14. 28. Forrás: undocs.org [2019. 04. 07.]

United Nations Security Council: Report of the Secretary-General on the situation in Somalia. [online], 2009. 07. 20. Forrás: undocs.org [2019. 04. 07.]

United Nations Security Council: Report of the Secretary-General pursuant to Security Council resolution 1846 (2008). [online], 2009. 11. 13. Forrás: undocs.org [2019. 04. 07.]

UNOSOM I (1992-1993). Forrás: peacekeeping.un.org [2019. 03. 13.]

UNOSOM II (1993-1995). Forrás: peacekeeping.un.org [2019. 03. 13.]

Új harckocsikat vesz a honvédség. [online], 2018. 12. 19. Forrás: honvedelem.hu [2019. 03. 12.]

Uj magyar rangidös nemzeti képviselö az EUTM-misszióban. [online], 2012. 03. 12. Forrás: honvedelem.hu [2019. 04. 09.]

Ünnep és medálparádé az EUTM Somalia misszióban. [online], 2012. 12. 12. Forrás: honvedelem.hu [2019. 04. 09.]

Weiss, Caleb: Shabaab targets Italian troops in Mogadishu with suicide bombing. [online], 2018. 10. 01. Forrás: longwarjurnal.org [2019. 04. 14.]

\section{Jogi források}

1100/2010. (IV. 28.) Korm. határozat. [online], Magyar Közlöny, (2010), 63. Forrás: kozlonyok.hu [2019. 04. 11.] Decisions Council Decision 2010/96/CFSP of 15 February 2010 on a European Union military mission to contribute to the training of Somali security forces. [online], 2010. 02. 15. Forrás: eur-lex.europa.eu [2019. 04. 07.]

Council Decision (CFSP) 2015/441 of 16 March 2015 amending and extending Decision 2010/96/CFSP on a European Union military mission to contribute to the training of Somali security forces. [online], 2015. 03. 16. Forrás: eur-lex.europa.eu [2019. 04. 14.]

Council Decision 2010/197/CFSP of 31 March 2010 on the launch of a European Union military mission to contribute to the training of Somali security forces (EUTM Somalia). [online], European Parliament, 2010. 03. 31. Forrás: europarl.europa.eu [2019. 04. 07.]

A Tanács (KKBP) 2016/2239 határozata (2016. december 12.) az Európai Uniónak a szomáliai biztonsági erők kiképzéséhez hozzájáruló katonai missziójáról szóló 2010/96/KKBP határozat módosításáról és meghoszszabbításáról. [online], 2016. 12. 12. Forrás: eur-lex.europa.eu [2019. 04. 14.]

A Tanács (KKBP) 2018/1787 határozata (2018. november 19.) az Európai Uniónak a szomáliai biztonsági erők kiképzéséhez hozzájáruló katonai missziójáról szóló 2010/96/KKBP határozat módosításáról és meghoszszabbításáról. [online], 2018. 11. 19. Forrás: eur-lex.europa.eu [2019. 04. 14.]

Council Decision 2011/483/CFSP of 28 July 2011 amending and extending Decision 2010/96/CFSP on a European Union military mission to contribute to the training of Somali security forces (EUTM Somalia). [online], 2011. 07. 28. Forrás: eur-lex.europa.eu [2019. 04. 07.]

Council Decision 2013/44/CFSP of 22 January 2013 amending and extending Decision 2010/96/CFSP on a European Union military mission to contribute to the training of Somali security forces. [online], 2013. 01. 22. Forrás: eur-lex.europa.eu [2019. 04. 09.]

Council Decision amending and extending Decision 2010/96/CFSP on a European Union military mission to contribute to the training of Somali security forces (EUTM Somalia). [online], European Council, 2011. 07. 25. Forrás: data.consolium.europa.eu [2019. 04. 07.] 